\title{
Plágio e contemporaneidade
}

DOI: $10.1590 / 1809-58442015218$

\section{Alisson Dias Gomes}

(Faculdade Santo Agostinho - FSA, Diretoria de Ensino, Cursos de Jornalismo e de Direito, e do Instituto Camillo Filho - ICF, Diretoria de Ensino, Cursos de Administração e de Arquitetura e Urbanismo, Teresina-PI, Brasil)

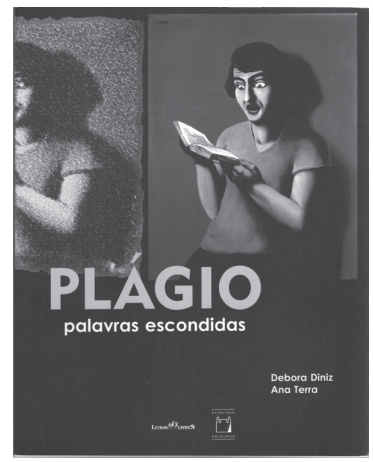

DINIZ, Débora; TERRA, Ana. Plágio: palavras escondidas. Brasília: Letras Livres; Rio de Janeiro: Fiocruz, 2014. 196 p.

editoração de livros facilitou a disseminação de opiniões,
ideias e pesquisas, seja por financiamento de editoras,
gráficas, coletivos de pesquisadores, pelo próprio autor ou por instituições de ensino e pesquisa, que com maior rapidez e facilidade disponibilizam materiais pertinentes e ricos para discussões atuais acerca de temas variados. Neste contexto, é imprescindível discorrer sobre Plágio: palavras escondidas (ano 2014), das autoras Debora Diniz e Ana Terra.

Trata-se de tema instigante e comum a realidade de todos, tanto na esfera escolar e universitária, como também nas dimensões social e profissional, tendo em vista que o ato de plagiar não se restringe a produções textuais, embora as reflexões mais frequentes recaiam neste âmbito. É importante dizer que não se trata de tema atual, mas a abordagem diferenciada e provocativa do assunto pode ser encontrada neste livro, uma vez que Diniz e Terra não definem o plagiador como ladrão nem atribuem ao plágio o rótulo de um crime tradicional. Optam por analisar o que 
acontece na academia e que pode estar na gênese de tal atitude comportamental, aliás, crescente em todas as esferas da produção científica e até literária. Isto porque, é comum o relato de docentes que desconfiados da diferença da produção diária de determinado aluno com o então exposto, ao "jogar" o último trecho do trabalho do aluno em algum site de busca, descobre o plágio, em maior ou menor escala, integral ou em partes e assim prossegue.

Plagia-se tudo, com maior ou menor constância, desde patentes de medicamentos, pesquisas científicas (artigos, capítulos de livros, trabalhos de congressos, monografias, dissertações e teses), fórmulas matemáticas com novas soluções, roteiros de filmes, letras de músicas, fotografias, projetos arquitetônicos, obras de artes, etc. Isto porque, como antevisto, há modalidades de plágio. Estas variam desde o tipo integral (cópia completa); tipo parcial (cópia fragmentada de parágrafos ou frases de um ou diversos autores); tipo conceitual (utilização da essência da obra do autor expressa de forma distinta da original); até chegar ao autoplágio, isto é, publicação de textos já publicados pelo autor, sem, no entanto, fazer referência aos trabalhos anteriores.

As autoras com sua experiência de vida e formação diversificada trazem à tona considerações ricas em detalhes. Enquanto Débora Diniz é antropóloga, documentarista e pesquisadora contumaz, Ana Terra é linguista, tradutora, especialista em gramática e editora de livros. Em comum, a paixão de ambas pelo mundo das letras. Isto faz com que elaborem um texto leve, conciso e direto. Eis uma etnografia do plágio, que privilegia desde abordagens controversas sobre o assunto a histórias de investigação em comitês internacionais até alcançar as páginas eletrônicas de trabalhos prontos.

Outro grande mérito das autoras é a busca de dar voz a autores e plagiadores. Nesta caminhada, passeiam pela arte, desde a escolha cuidadosa da capa ao usar a imagem da pintura "A leitora submissa" (ano 1928), de René Magritte e justificar, de forma sensível e coerente, os porquês de sua escolha. Prosseguem até a literatura, evidenciando que as práticas de plágio vão além do universo acadêmico, popularizando-se na sociedade 
contemporânea graças ao (in) devido uso dos recursos tecnológicos. A este respeito, as estudiosas incluem na discussão outra ideia preconcebida de que a Comunicação digital facilita a má conduta dos plagiadores, em especial, estudantes, de qualquer nível. Cada vez mais "preguiçosos" ou vivenciando o afrouxamento da educação formal, eles aproveitam as mil oportunidades que lhes são providas.

Sem exageros ou qualificações contidas, a obra de 196 páginas, editada por Letras Livres e Fiocruz, é isso tudo e um pouco mais. Num texto bem-humorado e elegante, as autoras desafiam as fórmulas prontas que descrevem o plágio como crime capital intelectual. De forma sutil, colocam o plágio como um malfeito que abala a integridade acadêmica. No entanto, em sua opinião, é preciso devolvê-lo ao campo pedagógico via discussões de caráter ético, em esferas e profissões variadas. Por tudo isto, Plágio: palavras escondidas consiste em livro indispensável a leitores, escritores, professores, estudantes e quaisquer cidadãos antenados com as mudanças que afetam o século 21.

\footnotetext{
Alisson Dias Gomes

Doutor em Comunicación Audiovisual, Revolución Tecnológica y Cambios Culturales, Universidad de Salamanca, Salamanca - Espanha. Docente da Faculdade Santo Agostinho (FSA) e do Instituto Camillo Filho (ICF). Concluiu mestrado em Comunicación y Educación pela Universidad Autónoma de Barcelona - Espanha. Professor da FSA e do Instituto Camillo FIlho (ICF), dos cursos: Arquitetura e Urbanismo, Comunicação Social Jornalismo, Direito, Engenharia Civil, Engenharia Elétrica, Psicologia, Serviço Social e Educação Física; coordenador institucional do programa Ciência sem Fronteiras na FSA; coordenador do Núcleo de Iniciação à Pesquisa da FSA. E-mail: alissondg@bol.com.br
} 